\title{
Effect of Herbal Feed Additives on Growth and Feed Costs of Broiler Chickens
}

\author{
Nikolaev Anastasia Igorevna and Lavrentiev Anatoly Yuryevich* \\ Professor, Chuvash State Agricultural Academy, Russia
}

Submission: January 23, 2019; Published: February 27, 2019

*Corresponding author: Lavrentiev Anatoly Yuryevich, Professor, Chuvash State Agricultural Academy, Russia

\begin{abstract}
The paper studies the effect of plant feed additive plant feed additive based on essential oils and plant substances on the growth and cost of feed, depending on the inclusion of different doses in the feed. The use of plant feed additives helps to increase the average daily live weight gain and reduce feed costs per unit of production. The best results were obtained with the addition of $0,015 \%$ of the dry matter of feed.

Keywords: Feed; Feed additive; Broiler chickens; Feed cost
\end{abstract}

\section{Introduction}

Currently, broiler production is developing successfully: highly productive meat crosses have been created; growing period 6-7 weeks; live weight reaches $2.0-2.2 \mathrm{~kg}$ with feed costs 1.7-2.03 kg per $1 \mathrm{~kg}$ of growth. However, the search for new methods of reducing the time of cultivation, increase in body weight and reduce the cost of feed per $1 \mathrm{~kg}$ of growth continues [1-3]. The successful development of the broiler industry led to advances in breeding work, the use of specialized feed, compliance with the recommended conditions of detention. More than $85 \%$ of eggs and poultry meat of the total volume produced by agricultural enterprises of the Russian Federation is produced by poultry enterprises and organizations - members of the Rosptitsesoyuz. [4-7].

The emphasis on the development of the poultry industry must be done not only by the fact that this is the most "ripening" industry, but also because under the conditions of limited grain resources, the greatest return per unit of feed, labor and other resources is achieved. The costs of feed and labor in poultry farming are 2-3 times lower than in pig and cattle breeding. Dietary poultry products are much cheaper than other types of products containing animal protein. Thus, from the standpoint of the interests of the population and the state in terms of solving the food problem, the development of the poultry industry should be carried out on a priority basis. [1-3]. To this end, the use of vegetable feed additives vegetable feed additive based on essential oils and vegetable as a feed additive to increase productivity and reduce feed costs per unit of production is relevant in industrial poultry farming. Herbal feed supplement based on essential oils and vegetable substances is designed to improve the taste and increase the palatability of feed poultry. The mechanism of action is based on the joint action of several plant substances in which there are active substances that, when mutually combined, affect a certain category of animals. The content of basic active substances is guaranteed with the possibility of their detection in premixes and compound feeds by analytical methods, both in quantity and quality. The composition of the feed additive "Biostrong 510" includes essential oils, herbal plants and seasonings. The carrier and excipients - wheat bran, limestone, silica, starch.

\section{Purpose of the Study}

The purpose of this work is to establish the feasibility and efficiency of enrichment of feed used in the production technology of broiler chickens, vegetable feed additive based on essential oils and vegetable substances.

\section{Materials and Research Methods}

To study the effectiveness of feeding plant feed supplements based on essential oils and plant substances in compound feeds for broiler chickens in the conditions of the poultry farm LLC Akashevskaya Poultry Farm LLC was conducted scientific and economic experience. To carry out the experiment according to the method of analogues, 4 groups of broiler chickens ( 1 control and 3 experimental) KOBB 500 cross-country at the age of 50 animals each were formed. Experiments were performed from daily to 40 days of age. The experiment was carried out according to the scheme presented in Table 1. In feeding the experimental broiler chickens, full-feed feed was used: PC 5-0 (pre-start, from 1 to 7 days), PC 5-1 (starter, from 8 to 15 days), PC 5-2 (grower 
/ height, s 16 to 22 days.), PK 6-1 (Finisher 1, from 23 to 34 days), PK 6-2 (Finisher 2, Art. 35 days). During the scientific and

business experience, experimental broiler chickens were placed on deep bedding with an outdoor content.

Table 1: Scheme of experience.

\begin{tabular}{|c|c|c|c|c|}
\hline Group & Livestock chickens' goal & The basic diet. feed & Age of bird. days & $\begin{array}{c}\text { The amount of “Bio strong 510". \% of } \\
\text { the dry matter of feed }\end{array}$ \\
\hline Control & 50 & PC 5-0 (prestarter) & $0-7$ & 0.01 \\
\hline I experienced & 50 & PC 5-1 (starter) & $15-$ Aug & 0.015 \\
\hline II experienced & 50 & PC 5-2 (grower / growth) & $16-22$ & 0.02 \\
\hline III Experienced & 50 & PC 6-1 (Finisher-1) & $23-34$ & \\
\hline & & PC 6-2 (Finisher-2) & ст. 35 & \\
\hline
\end{tabular}

Research results and discussion. Poultry growth is a complex biological process that occurs due to the interaction of the genotype and various technological factors (Table 2). It is possible to judge how the growth and development of broiler chickens proceeded when using vegetable feed additives based on essential oils and vegetable substances in the composition of feed, by the change in live weight during the entire growing period. Research has established that on average, the average daily gain in live weight over the entire growing period (40 days) was: in the control group - $51.46 \mathrm{~g}$, in the first experimental one - $53.70 \mathrm{~g}$, in the second experimental one $-55.82 \mathrm{~g}$, in the third experimental one $-55.53 \mathrm{~g}$.

Table 2: Change in average daily weight gain of broiler chickens. $\mathrm{g}$.

\begin{tabular}{|c|c|c|c|c|}
\hline Average daily gains in age: & Group Control & Group 1 Experienced & Group 2 Experienced & Group3 Experienced \\
\hline 1-7 days & $17.3 \pm 0.13$ & $18.4 \pm 0.41$ & $20.1 \pm 0.10$ & $19.1 \pm 0.24$ \\
\hline 8-14 days & $32.7 \pm 0.49$ & $36.2 \pm 0.15$ & $39.0 \pm 0.22$ & $37.7 \pm 0.34$ \\
\hline 15-21 days & $57.6 \pm 1.25$ & $60.0 \pm 0.68$ & $60.4 \pm 1.19$ & $60.0 \pm 2.23$ \\
\hline 22-28 days & $72.8 \pm 1.13$ & $75.1 \pm 0.99$ & $76.3 \pm 1.05$ & $75.7 \pm 1.03$ \\
\hline 29-35 days & $73.0 \pm 1.38$ & $76.5 \pm 1.85$ & $81.2 \pm 0.98$ & $82.9 \pm 1.66$ \\
\hline 36-40 days & $56.6 \pm 2.08$ & $57.0 \pm 2.68$ & $59.0 \pm 1.67$ & $58.5 \pm 0.74$ \\
\hline 1-40 days & $51.46 \pm 2.34$ & $53.70 \pm 3.02$ & $55.82 \pm 2.81$ & $55.53 \pm 2.67$ \\
\hline
\end{tabular}

The relative growth rate is an important indicator characterizing the intensity of the growth process of broiler chickens in a certain time period (Table 3). It is established that the relative growth rate at the beginning of the accounting period is higher, and by the end of the accounting period it decreases. In the experimental groups in the first 2 weeks the relative growth rate of broiler chickens was $163.83-166.32 \%$, against $161.26 \%$ in the control group. The highest relative growth rate for the accounting period of growing broiler chickens was observed in the $2^{\text {nd }}$ and $3^{\text {rd }}$ experimental groups, who received in their diets a vegetable feed additive based on essential oils and vegetable substances in an amount of 0.015 and $0.02 \%$ per 1 ton feed, respectively 192.76 and $192.71 \%$ (Table 4 ).

Table 3: The dynamics of the relative growth rate of broiler chickens. $\%$.

\begin{tabular}{|c|c|c|c|c|}
\hline Age period. day & Group Control & Group 1 Experienced & Group 2 Experienced & Group3 Experienced \\
\hline 1 -14 days & 161.26 & 163.83 & 166.32 & 165.17 \\
\hline 15-28 days & 95.02 & 105.38 & 102.43 & 103.78 \\
\hline $29-40$ days & 46.63 & 46.07 & 46.78 & 47.79 \\
\hline $1-40$ days & $192.14 \pm 0.03$ & $192.44 \pm 0.04$ & $192.76 \pm 0.06$ & $192.71 \pm 0.06$ \\
\hline
\end{tabular}

Table 4: Feeding and feed costs per $1 \mathrm{~kg}$ increase in live weight of broiler chickens for 40 days of cultivation $(n=50)$.

\begin{tabular}{|c|c|c|c|c|}
\hline Indicator & Group Control & Group 1 Experienced & Group 2 Experienced & Group3 Experienced \\
\hline Set. g & 4020.0 & 4020.0 & 4020.0 & 4020.0 \\
\hline Eaten from preset in: year \% & 3937.4 & 3947.6 & 3972.8 & 3967.7 \\
& 97.9 & 98.2 & 98.8 & 98.6 \\
\hline $\begin{array}{c}\text { The average consumption of feed for 1 } \\
\text { goal. per day. g }\end{array}$ & 98.4 & 98.7 & 99.3 & 99.2 \\
\hline The cost of feed per 1 kg increase in. M. Kg & 1.87 & 1.80 & 1.74 & 1.75 \\
\hline
\end{tabular}


When growing experimental broiler chickens, consumption of mixed fodders was recorded. According to this indicator, the cost of feed per $1 \mathrm{~kg}$ of weight gain was calculated. This indicator has a great impact on. In total, over the period of the experiment, $4020 \mathrm{~g}$ of mixed feed was used for each group. In the control group, the consumption of feed from a given amount was $97.9 \%$. Over the entire period of cultivation, the palatability of mixed feeds of the experimental groups was higher than the control group by $0.3 ; 0.9$ and $0.8 \%$. Feed consumption per 1 head per day in the first experimental group was $98.7 \mathrm{~g}$, which is more than the control group by $0.3 \mathrm{~g}$; in the second experimental group $-99.3 \mathrm{~g}$, which is more than the control group by $0.9 \mathrm{~g}$ and in the third experimental group - 99.2g, which is more than the control group by $0.8 \mathrm{~g}$. The cost of feed per $1 \mathrm{~kg}$ increase in live weight of broiler chickens in the control group is $1.87 \mathrm{k}$, and in the experimental groups this figure was lower by $0.07 ; 0.13$ and $0.12 \mathrm{~kg}$, respectively.

\section{Conclusion}

Thus, the use of vegetable feed additives based on essential oils and vegetable substances contributes to an increase in the average daily gain in live weight and meat qualities of carcasses. The best indicators were obtained with the inclusion of vegetable feed additives based on essential oils and vegetable substances in the amount of $0.015 \%$ of the dry matter of the feed.

\section{References}

1. Ivanova E, Lavrentiev A Yu (2015) The effect of enzyme preparations on egg production and the mass of laying hen eggs. Bulletin of the Ulyanovsk State Agricultural Academy. 1(29): 94-97.

2. Ivanova E, Lavrentiev A Yu (2014) Enzyme preparations in compound feeds for laying hens. Chief zoo-technician. 12: 37-41.

3. Ivanova E, Lavrentiev A Yu, Yakovlev VI, Yegorova TP, Terentyev A, et al. (2014) Effect of l-lysine fodder monochlorohydrate on egg productivity of hens. Poultry, 6: 35-37.

4. Lavrentyev A Yu, Nemtseva E Yu, Terentyev A Yu, Egorova TP, Sherne VS (2017) Compound feed with L-lysine monohydrochloride fodder when feeding laying hens. Agrarian science - agriculture: materials of the All-Russian scientific-practical conf Barnaul, Altai State Agrarian University, Russia, pp. 154-156.

5. Lavrentyev A Yu, Egorova TP, Terentyev A Yu (2014) L-lysine monochlorohydrate in layer rations of hens. Compound feed, 2: 51-53.

6. Lavrentyev A Yu, Egorova TP, Terentyev A Yu, Nemtseva A Yu (2015) L-lysine monochlorohydrate in layer rations of hens. Compound feed, 2: 83-85.

7. Nemtseva E Yu, Mikhailova LR (2017) Features of growing broiler chickens on an industrial basis. Environmental management and socioeconomic development of rural areas as the basis for the effective functioning of the agro-industrial complex of the region: materials of the All-Russian scientific-practical conference. with international participation. Cheboksary, Chuvash State Agricultural Academy, Russia, pp. $290-294$.

\begin{tabular}{l} 
Your next submission with Juniper Publishers \\
will reach you the below assets \\
- Quality Editorial service \\
- Swift Peer Review \\
- Reprints availability \\
- E-prints Service \\
- Manuscript Podcast for convenient understanding \\
- Global attainment for your research \\
- Manuscript accessibility in different formats \\
( Pdf, E-pub, Full Text, Audio) \\
- Unceasing customer service \\
Track the below URL for one-step submission \\
https://juniperpublishers.com/online-submission.php \\
\hline
\end{tabular}

